\title{
LA SERIE DE VISTAS ESTEREOSCÓPICAS DE ESPAÑA DE J. ANDRIEU Y UN PASEO POR EL MADRID DE $1867^{1}$
}

\author{
POR \\ MIGUEL HERVÁS LEÓN
}

\begin{abstract}
Presentamos un estudio de esta importante y poco conocida serie de 300 vistas estereoscópicas del fotógrafo francés Jean Andrieu, que constituye un retrato monumental y urbano de la España isabelina y que nos permite realizar un pequeño recorrido por el Madrid de 1867. Se acompañan explicaciones históricas y técnicas básicas sobre fotografía estereoscópica.

Palabras clave: Fotografía. Estereoscopia. España. Francia. Madrid. Isabel II. Turismo. Andrieu. Siglo XIX. Arquitectura. Urbanismo. Puertos marítimos. Museo del Prado.

In this study an important and little-known series of 300 stereoscopic views by the French photographer Jean Andrieu is presented. These photos constitute a monumental and urban portrait of Isabelline Spain, and permit us to take a mini tour of Madrid in 1867. The author includes historical and technical explanations of stereoscopic photography.
\end{abstract}

Key words: Photography. Stereoviews. Spain. France. Madrid. Isabel II. Tourism. Andrieu. 19th Century. Architecture. Urbanism. Marine ports. Prado Museum.

El proyecto de investigación Colección madridantiguo pretende recopilar y estudiar las imágenes históricas de Madrid capital, con especial interés por el medio fotográfico y, a la vez, contribuir al estudio de la Historia de la Fotografía en España. Así, desde el año 2001 trata de reconstruir «virtualmente» y estudiar algunas de las colecciones de vistas estereoscópicas de

\footnotetext{
${ }^{1}$ La ocasión de corregir unos datos erróneos de un número anterior de esta revista nos brinda la oportunidad de dar a conocer este proyecto. La vista 2665. Interieur de la galerie de sculpture du musée de Madrid se publicó en el artículo «La primera exposición de esculturas celebrada en el Real Museo de Pinturas» de Rose-De Viejo, Isadora (AEA, Tomo LXXVIII $n^{\circ} 309$, Enero-Marzo 2005, Pg 68), con algunos errores en el pie de foto, en cuanto a autor, fecha y colección, corregidos en el presente número. Esta vista se localizó o «descubrió», junto con otras dos similares -la 2666 y 2667-, dentro de la investigación Colección madridantiguo y fue publicada en el catálogo de la exposición El grafoscopio. Un siglo de miradas al Museo del Prado (1819-1920), Madrid, 2004 (pp. 109,113 y 114), del M. Nac. del Prado por los comisarios J.M. Matilla y J. Portús.

Quisiera aprovechar la ocasión para reconocer públicamente a las personas que de una u otra manera han colaborado en la elaboración del artículo: Mlle. Martinet de la Biblioteca Nacional de Francia, Isabel Ortega de la Biblioteca Nacional de Madrid, J.M. Matilla del Museo del Prado, Belén y Martín Carrasco de Casa Postal de Madrid, Agustín Moral, Luis Alba, J. Ramírez, G. Trotter, B. Summers, A. Hervás, N. Meléndez y D. Enrique Arias, director de esta publicación, por las facilidades concedidas.
} 
España que se publicaron entre aproximadamente 1855 y 1930, y concretamente, en este artículo, se trata de analizar una de las primeras y más extensas series: la de J. Andrieu.

Conocido el principio de la estereoscopia de antiguo y realizados algunos experimentos de visión estereoscópica con dibujos incluso antes del propio descubrimiento de la fotografía en 1839, el nacimiento de ésta, le aporta el soporte ideal para su objetivo de lograr la sensación de una tercera dimensión que permitiese ver las imágenes en relieve. Inmediatamente después ya se realizan algunas experiencias pioneras de fotografías estereoscópicas. Es en abril de 1850 cuando el fotógrafo e inventor escocés David Webster junto con los franceses Moigno, Soleil y Duboscq ${ }^{2}$, producen las primeras fotografías estereoscópicas y el primer visor en su forma definitiva. A partir de su presentación en la Exposición Universal de Londres de 1851 -donde suscita el interés de la reina Victoria-, la estereoscopia conseguirá una rápida y sorprendente difusión.

La imagen estereoscópica logra simular esta sensación tridimensional mediante el uso de dos imágenes muy similares yuxtapuestas, pero que realmente son distintas, ya que cada una reproduce la visión de uno de los dos ojos ${ }^{3}$. Esta sensación de tridimensionalidad nos hace creer que «estamos dentro» de la imagen y causaba un gran asombro en el espectador en el mundo pretecnológico de mediados del XIX -e incluso en el mundo hipertecnológico de hoy en día no deja de sorprender- ${ }^{4}$.

Este descubrimiento fue aprovechado comercialmente, con gran éxito, por los editores en un momento en el que existía en el mundo un gran deseo de conocimientos geográficos en general, y de los países extranjeros y exóticos en particular, lo que contrastaba con el alto coste y las aún grandes dificultades de los desplazamientos. En el caso de España, no cabe duda de que en ese momento el estereotipo transmitido en sus obras por numerosos escritores y viajeros, especialmente franceses e ingleses, era el de un país casi oriental, lo cual también se verá reflejado en las vistas que se publiquen, siendo siempre predominantes, como veremos, los temas y monumentos árabes y las imágenes más costumbristas.

Por los motivos expuestos y por su relativo bajo coste -que en los primeros años se redujo fuertemente-, la contemplación de imágenes estereoscópicas en general (incluyendo escenas domesticas, de fantasía, retratos, desnudos, etc.) y de vistas topográficas, en especial, pronto se convirtió en el pasatiempo de moda entre la burguesía de la segunda mitad del siglo -comenzando su declive hacia 1880, pero subsistiendo hasta la década de 1930-, y en muchos casos, los más pudientes no se conformaban con las vistas editadas comercialmente en grandes tiradas, sino que realizaban sus propias vistas con cámaras fotográficas específicas ${ }^{5}$.

Destinadas principalmente al público del país del editor -como en nuestro caso demuestra el uso exclusivo del idioma francés en los textos-, las vistas también se solían distribuir en otros mercados y en el propio país representado. A los pocos años se comenzaron a producir múltiples series, por numerosos fotógrafos, de mayor o menor extensión, de los lugares más insospechados.

\footnotetext{
${ }^{2}$ Ante el escaso interés mostrado por los ópticos ingleses y sus dificultades para fabricar un visor estereoscópico, Webster se desplaza a París donde el religioso Moigno ve las grandes posibilidades del invento y consigue que los ópticos Soleil y su sobrino Duboscq fabriquen un visor.Ver Nazarieff, Serge, Early erotic photography, Ed. Taschen 2002 , p. 7.

3 Realmente se trataría de obtener una fotografía de la imagen que ve el ojo izquierdo -sólo- y otra de lo que ve el derecho. Para lograrlo, al igual que sucede en nuestra visión normal de la realidad, se desplaza el punto de mira de una a otra imagen -en este caso el objetivo de la cámara- hacia un lado unos $7-10 \mathrm{~cm}$. Con estas imágenes $-\mathrm{y}$ con la ayuda de un visor con lentes especiales- se «engaña» a nuestro cerebro, que fusiona ambas imágenes y nos hace creer que estamos viendo la imagen en relieve.

${ }^{4}$ Para una completa historia de la fotografía estereoscópica y de sus principios, en español, ver: Fernández Rivero, J.A., Tres dimensiones en la historia de la fotografía estereoscópica: La imagen estereoscópica, Ed. Miramar, Málaga 2004.

${ }^{5} \mathrm{El}$ par de imágenes estereoscópicas se puede lograr usando, bien una cámara normal, que se desplaza lateralmente para la segunda toma, bien usando dos cámaras yuxtapuestas o bien mediante una cámara binocular.
}

AEA, LXXVIII, 2005, 312, pp. 381 a 396 

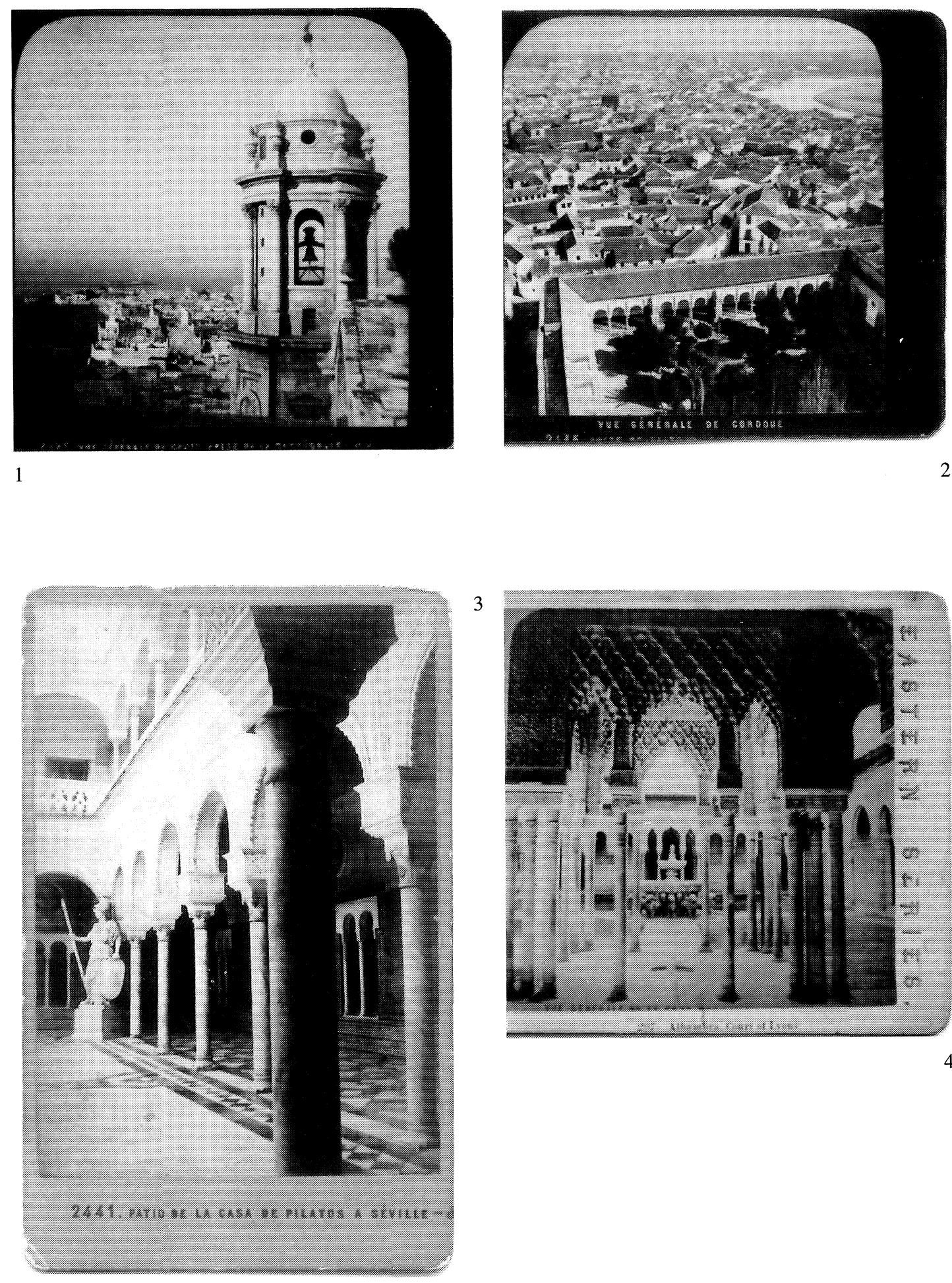

3

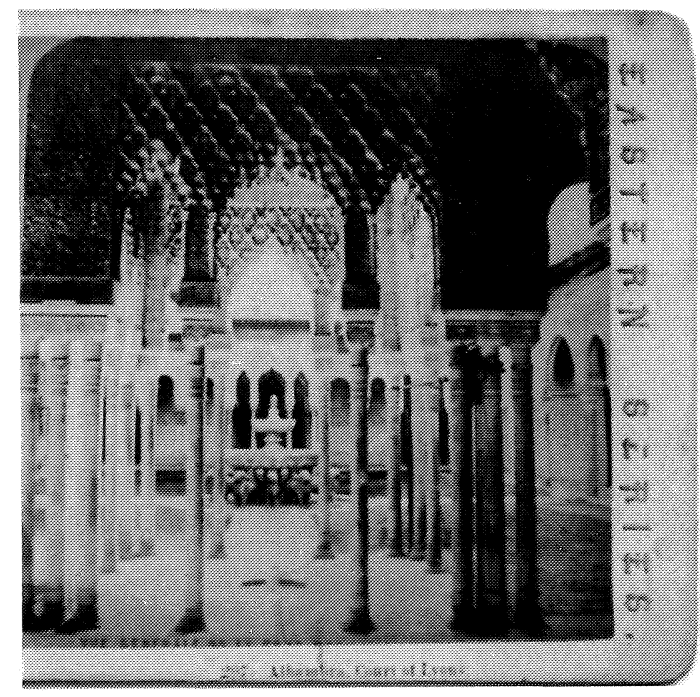

Fig. 1. 2426, Vue générale de Cadix prise de la cathédrale. (J.A., $1^{\text {a }}$ Edición), Colección madridantiguo.

Fig. 2. 2435, Vue générale de Cordoue prise de la tour de la mosquée. (J.A., $1^{a}$ Edición), Colección madridantiguo. Fig. 3. 2441, Patio de la casa de Pilatos á Séville. (J.A., $2^{\mathrm{a}}$ Ed., en formato CdV), Colección madridantiguo.

Fig. 4. Copia pirateada del patio de los leones de la Alhambra de Granada., Colección madridantiguo.

* Por razones de espacio de la mayoría de las vistas sólo se ha reproducido la mitad derecha. 
En el caso de España, realizaron vistas estereoscópicas los españolizados Charles Clifford y J. Laurent, entre otros muchos fotógrafos locales. Entre las series sobre la península editadas en el extranjero en la época dorada de la estereoscopía, las más conocidas son: las de Ferrier et Soulier, las de sus sucesores León et Levy y las muy populares de Ernest Lamy -con poco más de 100 vistas-, de Alexis Gaudin -algo más de 400- y la que nos ocupa de J. Andrieu -312-.

\section{El fotógrafo $J$. Andrieu}

Como en toda investigación sobre fotografía decimonónica, la primera sorpresa que uno se encuentra es la escasez de datos disponibles. El relativo interés que ha existido por estos temas hasta fechas bastante recientes ha permitido que mucha información, documentos, materiales y archivos se hayan perdido o destruido.

Esto se refleja en el hecho de que, en este caso, ni siquiera se pueda afirmar con seguridad el nombre del fotógrafo, ya que suele figurar como J.A. o como J. Andrieu. Si bien actualmente se acepta el nombre de Jean, que habría nacido en 1816 en Montaigu (Francia) ${ }^{6}$, tampoco es un dato seguro y a menudo se le sigue reflejando como Jules, el nombre que anteriormente se creía correcto ${ }^{7}$.

Publicó grandes series de vistas de Francia -Voyage aux Pyrénées-, Italia, Suiza y Saboya antes de la de España (que incluyó Gibraltar) y más tarde también publicó vistas de Palestina, Siria y Egipto. No publicó vistas de Portugal ${ }^{8}$, al contrario que otros editores que a veces fotografiaban ambos países peninsulares a la vez ${ }^{9}$.

En cualquier caso, su serie sobre ciudades costeras de 1862, Villes et ports maritimes de l'Ocean et de la Méditerranée -posiblemente relacionada con su trabajo como fotógrafo del ministerio de marina o tal vez a ella debiese su nombramiento como tal- y las vistas de los «Desastres» producidos en Paris durante la Comuna de 1871 son las que mayor fama como fotógrafo le reportaron ${ }^{10}$.

Entorno a 1872 el editor Adolphe Block se hizo cargo de su archivo y comenzó a publicar sus vistas bajo la marca B.K. Además de producir otras series, continuó utilizando los negativos de Andrieu y, a pesar de cambiar el diseño de los cartones, generalmente mantuvo los títulos, numeración y la «firma» JA.

En general, a pesar de saber el editor de una vista estereoscópica o de llevar ésta una marca o «firma», es difícil afirmar quien ha tomado realmente la fotografía, ya que era frecuente la compra de negativos, el uso de ayudantes o incluso contratar o enviar un fotógrafo a modo de corresponsal. Este sería, por ejemplo, el caso de Ferrier, quien publicó vistas tomadas por otros fotógrafos, y así, las vistas de su serie española parece ser que pudieron ser realizadas por varios fotógrafos, con al menos las vistas de Segovia probablemente tomadas por Clifford. En nuestro caso, se puede asegurar que Andrieu realizó personalmente las imágenes, ya que él mismo nos lo dice en el prólogo de su catálogo: «... du nouveau voyage stereoscopique que je viens de faire en Espagne...» ${ }^{11}$ y por lo demás, parece que el conjunto de la serie mantiene una gran uniformidad de estilo y de fechas.

\footnotetext{
${ }^{6}$ Pellerin, Denis, La photographie stereoscopique sous le second empire, París, BNF 1995, p. 103.

${ }^{7}$ Así en el propio cat. expo. op. cit. El grafoscopio, p. 295.

${ }^{8}$ Para un completo estudio de las estereoscópicas portuguesas ver la web: www.fe.up.pt/ jmf/stereo

${ }^{9}$ Por ej. la serie de F.Blanc de Vues stereoscopiques de L'Espagne et du Portugal de los mismos años que la serie de Andrieu.

${ }^{10}$ Dictionnaire mondial de la photographie, París, Ed.Larousse 1994, p. 32.

$"$ Andrieu, J. Catalogue des vues stereoscopiques des Pyrenées ... Nouvelle collection de l'Espagne photographiées et edités par J.Andrieu, París 1868.
}

AEA, LXXVIII, 2005, 312, pp. 381 a 396 

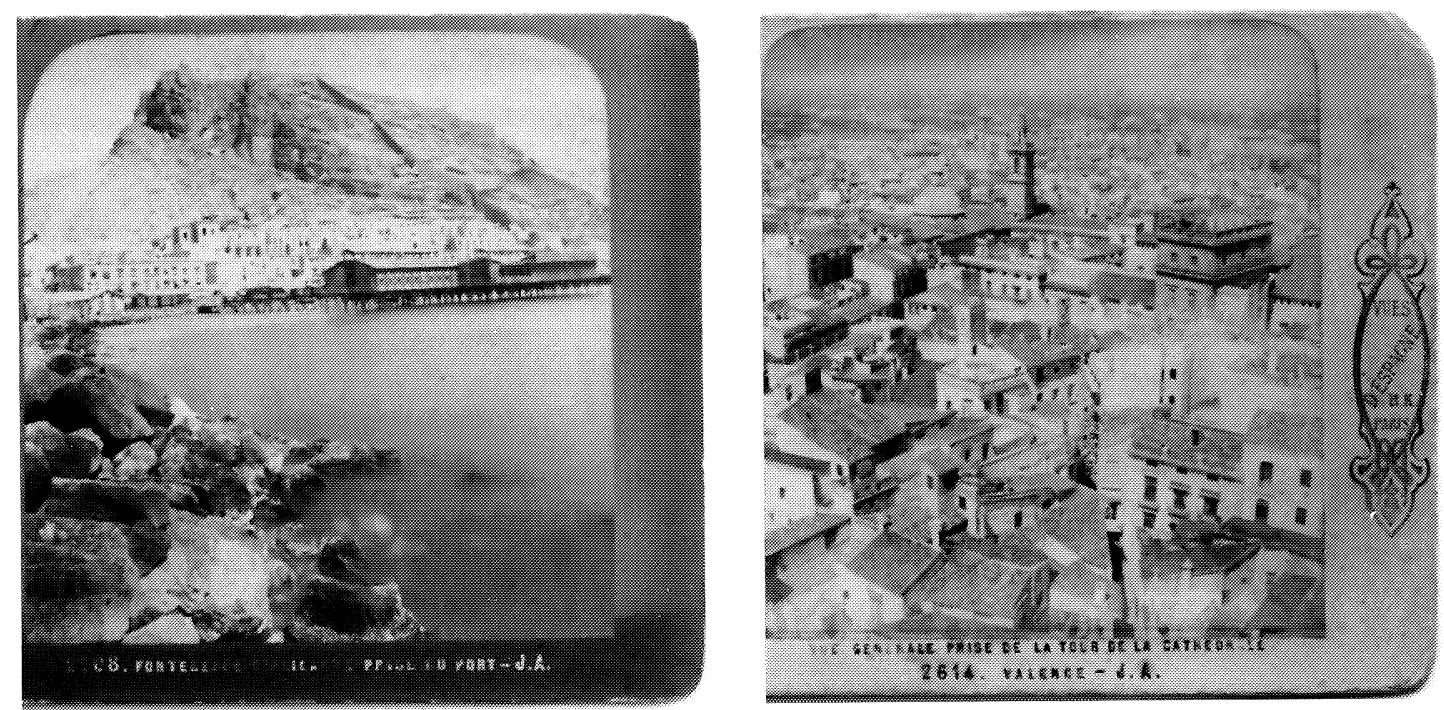

5

7

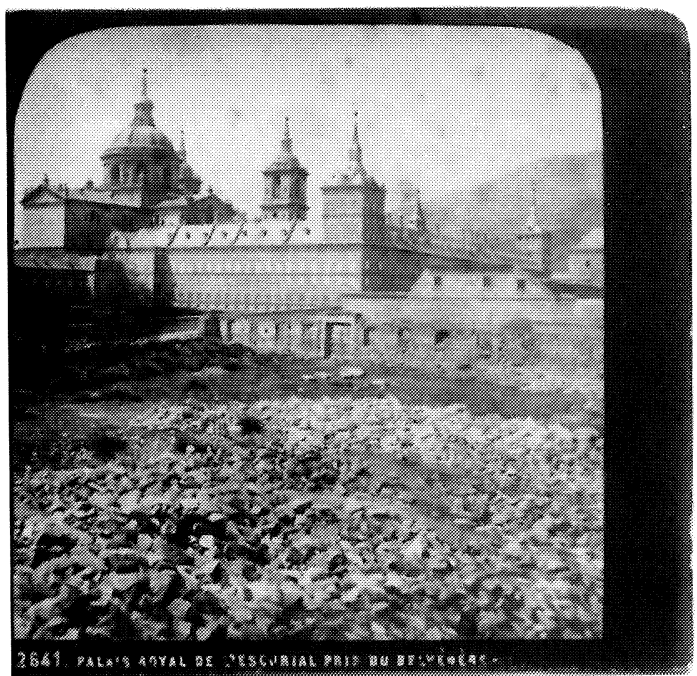

Fig. 5. 2608, Forteresse d'Alicante prise du port. (J.A., $1^{\text {a }}$ Edición), Colección madridantiguo.

Fig. 6. 2614, Vue générale prise de la tour de la cathedrale Valence. (Edición B.K.), Colección madridantiguo.

Fig. 7. 2641, Palais Royal de l'Escurial pris du belvédere. (J.A., $1^{a}$ Edición), Colección madridantiguo.

Fig. 8. 2651, Le Tage et le pont de l’Alcantara Toléde. (Edición B.K.), Colección madridantiguo.

\section{La serie de España y Gibraltar de J. A.}

La serie de vistas españolas se puede fechar con bastante certeza en 1867 o, como máximo, a principios de $1868^{12}$ y se publicó, manteniendo las imágenes, con diversas presentaciones en sus sucesivas ediciones a lo largo de bastantes años.

\footnotetext{
${ }^{12}$ Andrieu realiza el depósito legal de estas vistas en la Biblioteca Nacional de Francia el 27 de Agosto de 1868, lo que considerando el tiempo necesario para su realización física nos lleva a las fechas indicadas. Algunos detalles arquitectónicos que se aprecian en las imágenes nos sitúan en esos mismos años.
} 
La que parece ser la primera edición comercial de las vistas estereoscópicas (ver Figs. 1, $2,5,7,10,13$ y 18) tiene un soporte de cartón de tamaño $17,5 \times 8,7 \mathrm{~cm}$. con esquinas redondeadas, anverso de papel satinado de color violeta -con reverso en rosa grisáceo, sin inscripciones- y en la parte inferior derecha el título en francés, junto al número de serie y la marca JA, todo ello con letras mayúsculas finamente troqueladas en relieve de color blanco. Las fotografías en papel a la albúmina van adheridas al cartón y se componen de dos imágenes de $7,6 \times 5,8 \mathrm{~cm}$. cada una, con corte entre ambas -aunque casi yuxtapuestas- y ligeramente redondeadas en las esquinas superiores y cuadradas en las inferiores. Tal vez sea este su modelo más logrado y a la vez el más original, frente a la gran mayoría de editores que utilizaban las gamas de amarillos y naranjas.

La siguiente edición es idéntica a la anterior (ver Figs. 9, 11, 14, 16 y 17), salvo por el hecho de ser el papel del anverso de color naranja -reverso gris- y los textos en rojo. Con esta misma presentación publicó también -al igual que hicieron otros editores de vistas, como por Ej. E. Lamy-, algunas imágenes en formato Carte de Visite $-10,6 \times 6,8 \mathrm{~cm} .-$ (ver Fig. 3), con una sola de las imágenes, aunque aprovechando un poco más el negativo para obtener una vista ligeramente más panorámica $-9 \times 5,2 \mathrm{~cm}$. - y con el texto en la parte inferior o en el lateral derecho, según la vista sea horizontal o vertical. Este formato no debió producirse en grandes cantidades, tal vez por no obtener éxito entre el público, a la vista de los escasos ejemplares conservados.

Las siguientes ediciones ya fueron realizadas por Adolphe Block, que utilizó diversos modelos de cartones, de inferior calidad y acabado, con colores amarillos o naranjas, con orlas y dibujos impresos o incluso troquelados en relieve, la marca Vues d'Espagne B.K. Paris y según el modelo, aunque no siempre, manteniendo los textos, la numeración e incluso la firma JA. (ver Figs. 6, 8, 12 y 15).

Block también editó las mismas vistas, o al menos algunas de ellas, en otras dos novedosas presentaciones:

- Como dioramas -conocidas como tissues-: (ver Fig. 15) Las mismas fotografías montadas al aire con un cartón que sólo sirve de marco, de tal manera que si bien el aspecto normal es similar, dentro de la caja-visor y con iluminación posterior, la luz que traspasa produce un efecto de iluminación nocturna y/o coloreado. Esto último se logra añadiendo al dorso del papel fotográfico un sencillo coloreado coincidente con los detalles de la imagen (Ej. Tejados en rojo) y un fino papel manila traslúcido como protección. También suelen llevar una serie de mínimas perforaciones en lugares estratégicos, coincidentes con ventanas, farolas..., produciéndose el efecto de una bombilla iluminada o incluso del sol o la luna si se ha logrado una mayor transparencia mediante una mancha aceitosa.

- Como Simil Verre. De aspecto similar a una diapositiva en ByN actual. Usando en lugar de papel fotográfico un fino «celuloide» transparente con la imagen impresa en negro, simulando, como su nombre indica, un cristal, otra de las presentaciones que, aunque menos habitual, existían en el mercado.

Existen unas vistas, con numeración más baja -1885 a 1906-, de localidades de Guipúzcoa (San Sebastián, Pasajes de San Juan y Fuenterrabía) que en su origen no pertenecían a esta serie general, sino a la serie francesa sobre los Pirineos, de $c a$. 1862, que junto a vistas de Francia ${ }^{13}$ incluyó algunas de localidades españolas cercanas a la frontera muy visitadas por los turistas franceses. Existen con cartón en azul claro y en violeta. Estas mismas imágenes fueron usadas luego en la serie general, pero con distinta numeración -2710 a 2733- (Ej. la 1898 pasa a ser la 2715 , la 1900 la $2716 \ldots$.).

${ }^{13}$ La vista 1884 corresponde a San Juan de Luz y la 1907 a Burdeos, anterior y posterior respectivamente.

AEA, LXXVIII, 2005, 312, pp. 381 a 396 


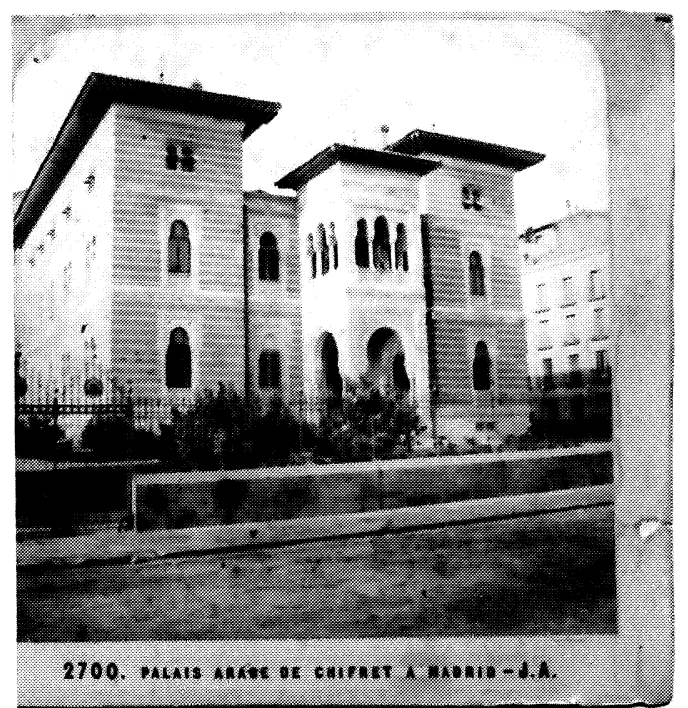

9

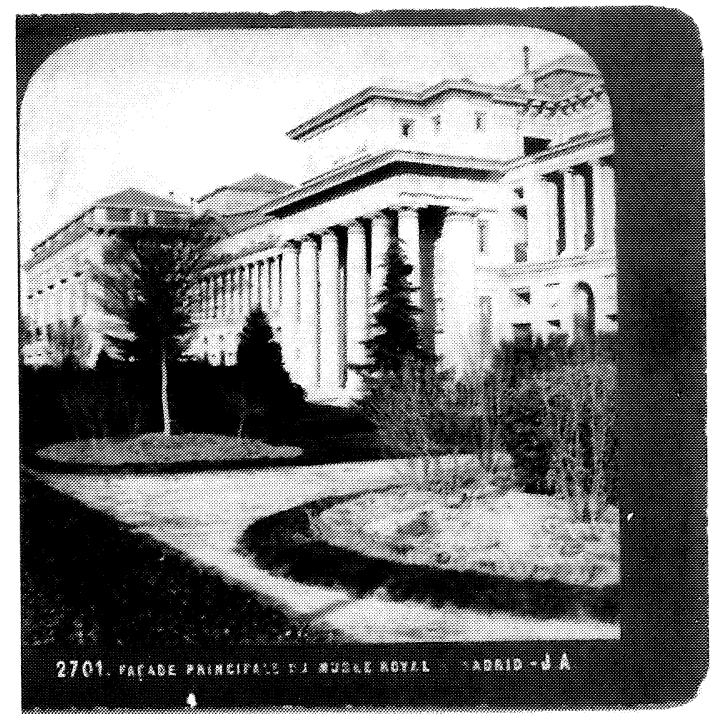

10

11

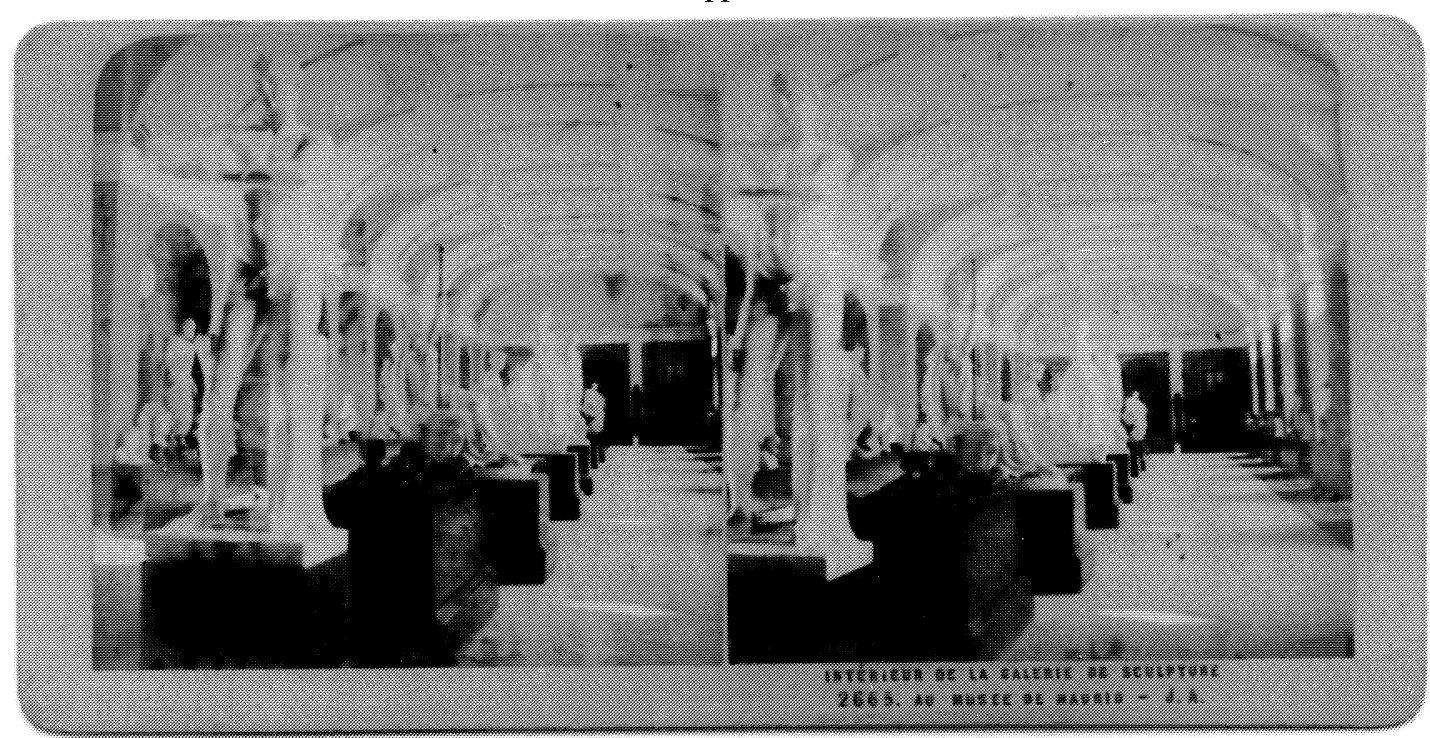

Fig. 9. 2700, Palais arabe de Chifret a Madrid. (J.A., $2^{\mathrm{a}}$ Edición), Colección madridantiguo.

Fig. 10. 2701, Façade principale du musée royal a Madrid. (J.A., $1^{\text {a }}$ Edición), Colección madridantiguo.

Fig. 11. 2665, Interieur de la galerie de sculpture au musée de Madrid. (J.A., $2^{\mathrm{a}}$ Edición), Colección madridantiguo.

Análisis de las vistas

Dado lo extenso de la serie y las características de esta publicación, sólo es posible publicar la lista de las vistas, realizar un breve análisis de las características generales, especialmente desde un punto de vista fotográfico, y estudiar algunos ejemplos -con más detalle en el caso de las vistas de Madrid-, dejando para mejor ocasión y lugar un análisis en profundidad desde un punto de vista monumental, urbanístico e histórico del conjunto y de cada vista.

Las vistas de la serie general, como hemos dicho, llevan una numeración, que es continua entre el 2422 y el 2723 y están ordenadas siguiendo un recorrido, por lo que, para un más fácil análisis, hemos dividido la lista por localidades (ver «Listado de la serie» anexo). 
Un primer análisis de las numeraciones y poblaciones nos lleva concluir que la serie se compone de 312 vistas -aunque Andrieu hablase en su catálogo de cerca de 300-, ya que 4 números no existen y 14 tienen numeración duplicada, unos tal vez por olvidos y otros, en el que las vistas son casi idénticas, son de difícil justificación. Analizando los grupos vemos que en ellas se representan:

- 3 capitales con series «amplias»: Sevilla con 75 vistas; Granada con 52; Madrid con 42. (En conjunto concentran más del $50 \%$ del total).

- 7 series «medianas»: Toledo, 23; Barcelona, 17; Córdoba y Guipúzcoa (como conjunto), 14; Málaga y Cartagena, 11; Gibraltar, 12.

- 6 series «menores»: Valencia y Aranjuez, 9; El Escorial, Burgos y Cádiz, 6; Alicante, 5.

Nos puede sorprender la presencia de algunas poblaciones y la importancia relativa concedida a cada una. Así la de los pueblos guipuzcoanos, por los motivos ya explicados, o la de Cartagena o Alicante, que probablemente deban su inclusión a su condición de puertos importantes, ya que, según hemos dicho, Andrieu había publicado una serie sobre puertos marítimos -si bien sólo franceses, por lo que aquí no reaprovechó el material-.

Frente a estas inclusiones también nos pueden llamar la atención algunas ausencias, como las de Segovia, Salamanca, Valladolid, León o Zaragoza, o por el norte Bilbao, Santander o Santiago, lo que en algunos casos probablemente se deba a una simple elección personal -ya que otros editores sí incluyeron algunas de estas ciudades-, y en otros a su localización alejada del resto, las dificultades del desplazamiento y a su relativamente escasa importancia monumental en la época -o a la que se les reconocía-, lo cual muchas veces las excluía de las rutas habituales de los viajeros reales y, en este caso, también de las de los virtuales.

Las rutas generalmente dependían del lugar de origen del viajero y del medio de transporte utilizado, que solía ser terrestre, entrando por la frontera francesa -bien por Irún o por Port Bou-, o marítimo -por el norte Vigo o por el sur Cádiz o Gibraltar-. En el primer caso la ruta sería, con mayor o menor amplitud y extensiones laterales en función del interés y del tiempo: Irún, Burgos, Madrid, Toledo, Andalucía, Levante y Cataluña, o a la inversa, y en el caso del viaje marítimo, se solía visitar primero Andalucía y luego otras ciudades del interior y/o de la costa.

Este segundo caso fue el elegido por Andrieu en la edición de las vistas, ya que en la realidad parece ser que realizó el viaje por tierra, al menos en su mayor parte, por lo que entraría por la frontera y si alguna parte del viaje la realizó en barco, lo lógico sería que hubiese descendido o remontado por la costa ${ }^{14}$. La serie recorre así, como podemos ver en la lista, primero Andalucía, remontando luego por todo el Levante hasta Barcelona y se adentra en el interior hacia Madrid y sus cercanías, para finalmente dirigirse por Burgos hasta la misma frontera de Irún, como nos indica la vista 2710 del puente internacional de Hendaya.

Un análisis de las vistas por tipos y una observación directa de las imágenes nos permite deducir que Andrieu tenía preferencia por 3 tipos de imágenes:

- Vistas generales o panorámicas de una ciudad, barrio o paisaje, con carácter aéreo o semiaéreo, al tomarse desde una construcción humana -torre o faro- (Ver Figs. 1, 2, 6 y 15) o, aprovechando la orografía, desde un accidente natural, como una ladera o el valle de un río (Ver Figs. 5 y 8). Varias de estas vistas no faltan en casi ninguna población.

${ }^{14}$ Sería interesante investigar si, de alguna manera, el viaje o la serie tuviese que ver con su título oficial, obtenido en 1865, ya que no es infrecuente el caso del fotógrafo al que se le relaciona con posibles actividades políticas o de «espionaje». Por otra parte, en esta época relativamente avanzada el interés de las imágenes de lugares estratégicos -como pueden ser los puertos-, y las sospechas que solían levantar sus actividades, ya no eran las mismas que unos años antes. Así, en el propio catálogo se señalan las ayudas y facilidades recibidas en todos los lugares y por parte de numerosas personas y de las autoridades, contrastándolas con las dificultades que eran habituales anteriormente. Al propio Clifford se le sospechan actividades de este tipo, ver Fontanella, Lee y Gerardo F. Kurtz Charles Clifford, fotógrafo de la España de Isabel II Ed. El Viso, Madrid 1996, pp. 13 y 46.

AEA, LXXVIII, 2005, 312, pp. 381 a 396 


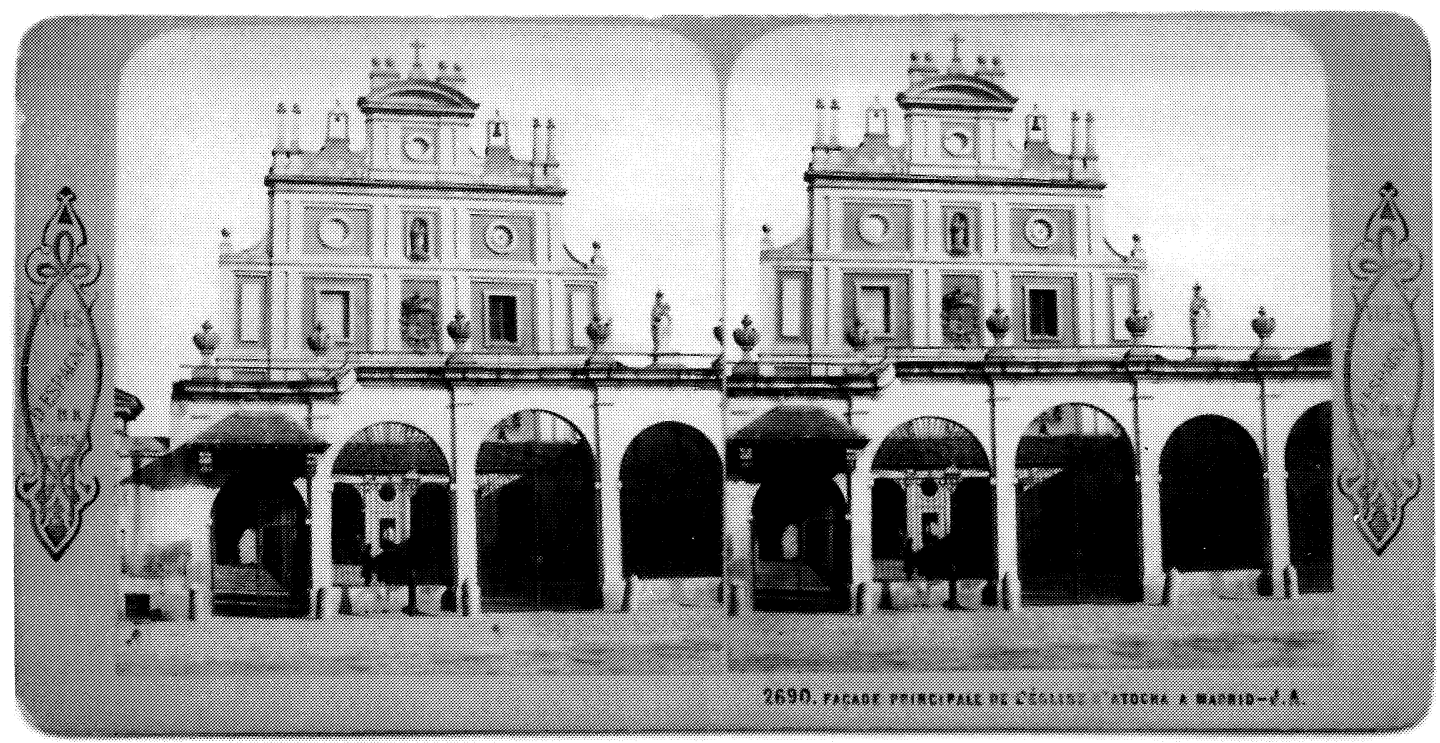

12

13

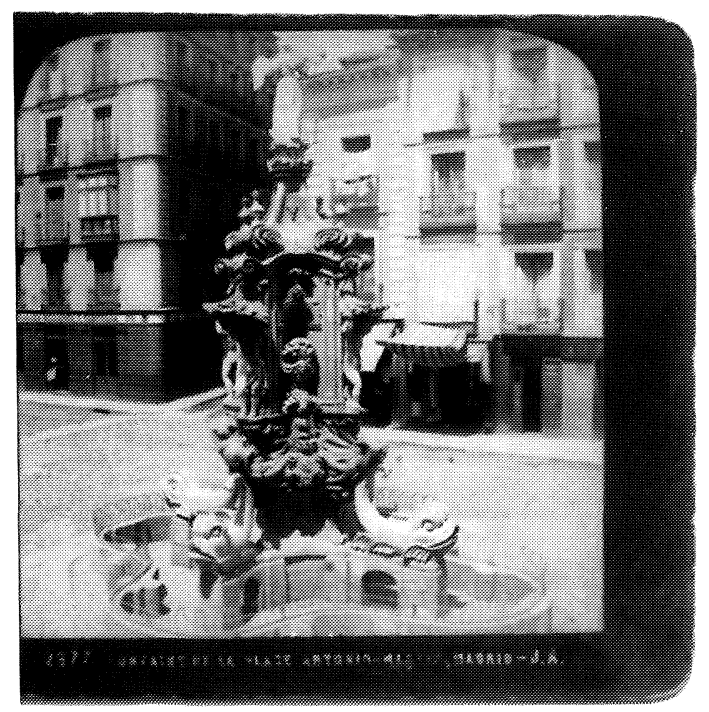

14

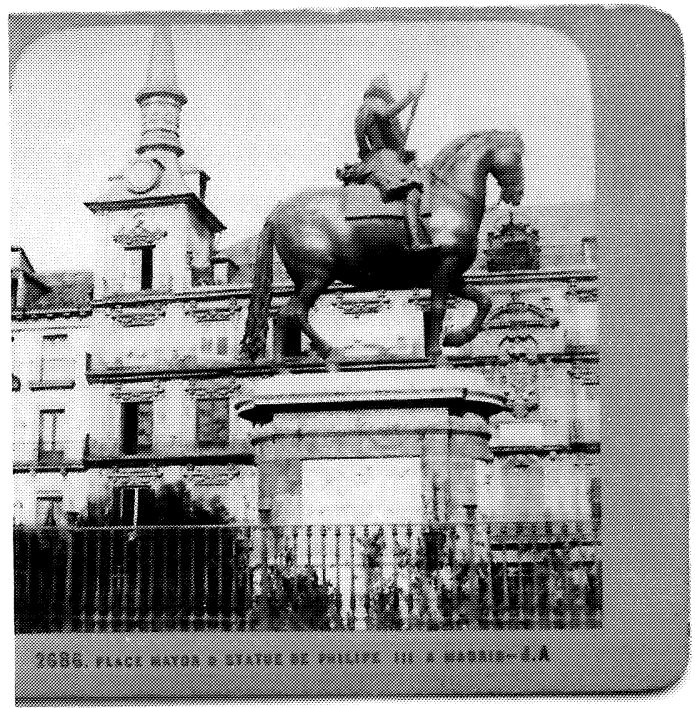

Fig. 12. 2690, Façade principale de l'église d'Atocha a Madrid. (Edición B.K.), Colección madridantiguo. Fig. 13. 2677, Fontaine de la place Antonio (sic) Martín Madrid. (J.A., $1^{\mathrm{a}}$ Edición), Colección madridantiguo. Fig. 14. 2686, Place mayor \& statue de Philipe III a Madrid. (J.A., $2^{\mathrm{a}}$ Edición), Colección madridantiguo.

Esto produce vistas muy generales sobre los tejados o el paisaje natural, lo que en el reducido espacio de una imagen de este tamaño supone un detalle y una definición limitados. En principio es una idea interesante desde un punto de vista estereoscópico, ya que, si se consiguen tomar en la vista elementos muy cercanos y otros lejanos, la sensación de relieve por el contraste, será mayor. En la práctica, Andrieu no solía conseguir los mejores resultados, como les pasaba a muchos de los fotógrafos de primera época.

- Primeros planos. Vistas muy cercanas de algún elemento monumental, generalmente eliminando todo elemento contextual del entorno (Ej. en el caso de una fuente, la plaza donde se halla) o del propio edificio al que pertenece el detalle (Ej. una puerta de una catedral) y en 
algunos casos sin ni siquiera reproducirse el edificio completo en otra vista. Así encontramos numerosas vistas de monumentos (fuentes, estatuas y puertas monumentales) (Ver Figs. 13, 14 y 18), de detalles (puertas de catedrales o palacios) y tan solo unas pocas vistas cercanas de la fachada completa de algún edificio o de un puente (Ver Figs. 7, 9, 10 y 12). Lógicamente, al contrario que en el caso anterior, esto no favorece el efecto estereoscópico del relieve.

- Interiores. De igual forma que en los primeros planos, a veces parece que le dio más importancia -al menos por el número de vistas- a los interiores que al edificio en sí o a su aspecto exterior. Así encontramos múltiples vistas de salones palaciegos (Sevilla y Madrid) y de patios islámicos (Sevilla y Granada). (Ver Figs. 3, 4, 11 y 17).

Analizándolas por temas, observamos que tenía una especial predilección por las vistas de puertos, lo cual se refleja en el gran número de ciudades costeras representadas, normalmente con varias vistas generales de cada uno. Además del motivo principal, ya expuesto, las vistas de puertos y barcos siempre presentan mayor animación, lo cual, al contrario que los primeros planos, produce vistas de gran belleza.

También cabe destacar que, como muchos de los fotógrafos de la época, prácticamente huía de la representación de personas o incluso de animales, por lo que es muy raro que en sus vistas se vea una figura humana, ni siquiera de forma lejana o casual y tan solo, en algún caso excepcional, parece incluir a alguien a propósito. Por ello cuando en la vista 2661 de Toledo encontramos a un señor en primer plano posando sobre un fondo del río Tajo y la ciudad, podemos pensar que se trata de alguien cercano al propio fotógrafo, o más aún, en la vista 2429 de Córdoba, cuando un caballero posa delante de la cámara, cuya sombra vemos proyectada en el suelo -no así claramente la del fotógrafo-, cabe pensar que pudiera ser incluso él mismo -lo cual sería también de interés poder comprobar-. Esta costumbre de incluirse uno mismo en la imagen -a modo de autorretrato- no era del todo infrecuente entre los fotógrafos de la época ${ }^{15}$, como tampoco lo había sido entre los pintores. La ausencia de personas se puede explicar, en parte, por las dificultades que suponía el fotografiar figuras vivas que se solían mover -así en las vistas de muchos fotógrafos a menudo aparecen «movidas»-, ya que para lograr buenos resultados tenían que estar unos minutos inmóviles -si bien por estas fechas se había avanzado mucho en éste problema y estaba prácticamente superado si nos atenemos a vistas urbanas de otros fotógrafos contemporáneos-. Por otra parte, probablemente también se deba a una elección estética personal, ya que si se deseaba incluir figuras, se podía recurrir a una persona que posara el rato necesario. Así otros fotógrafos solían recurrir, por ejemplo, a la figura de un gitano o una gitana, con sus vestidos tradicionales y con o sin burro -todo lo cual resultaba muy atractivo para los extranjeros-, para animar las vistas de la Alhambra, pero no así en nuestro caso. Esto es una pena ya que, como hemos dicho para el caso de los puertos, las vistas animadas son siempre más atractivas, aparte del interés intrínseco que puedan tener las figuras retratadas.

Como ya indicamos al principio e incluso nos señala Andrieu en el propio catálogo, existía un gran interés por el pasado islámico de España, lo que motivó que incluyese numerosísimas vistas -a veces incluso repetitivas: como 20 vistas del Patio de los Leones de la Alhambra-, de estos monumentos de Granada, Sevilla, Córdoba, Toledo e incluso Madrid, ya sean de época o posteriores (ver Figs. 4, 3, 2 y 9). Por el contrario, se observa un escaso o nulo interés por los monumentos romanos, visigodos o románicos, algo más por los góticos (Valencia, Sevilla, Burgos) y ya mayor por los de épocas posteriores, como pueden ser por ejemplo la mayoría de los de Madrid.

\footnotetext{
${ }^{15}$ Sobre algunos presuntos autorretratos de Laurent ver el artículo de Gutiérrez Martínez, Ana J.Laurent, creador, in novador y maestro de la fotografía en el catálogo Jean Laurent en el Museo Municipal de Madrid Tomo I Artistas plásticos, M.M.de M., Madrid 2005, pp. 27 y 29.
}

$A E A$, LXXVIII, 2005, 312, pp. 381 a 396 


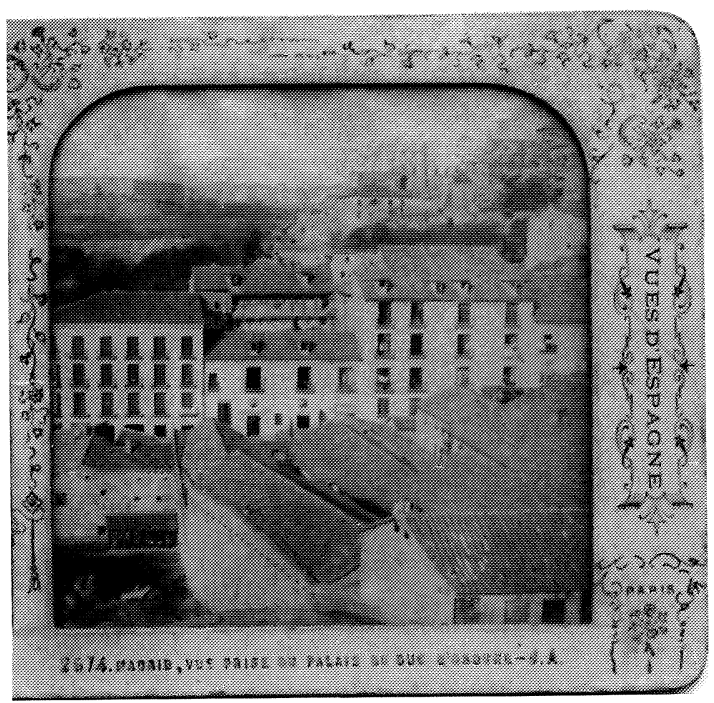

15

17

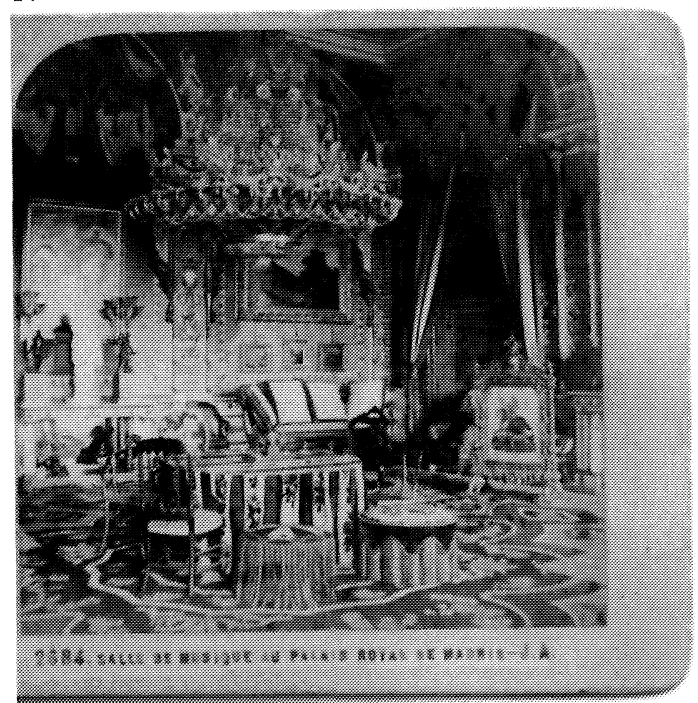

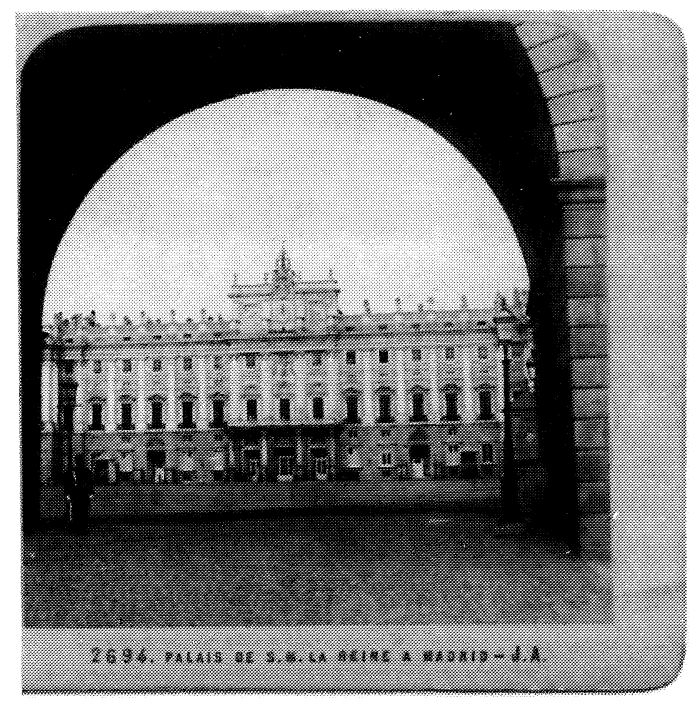

16

18

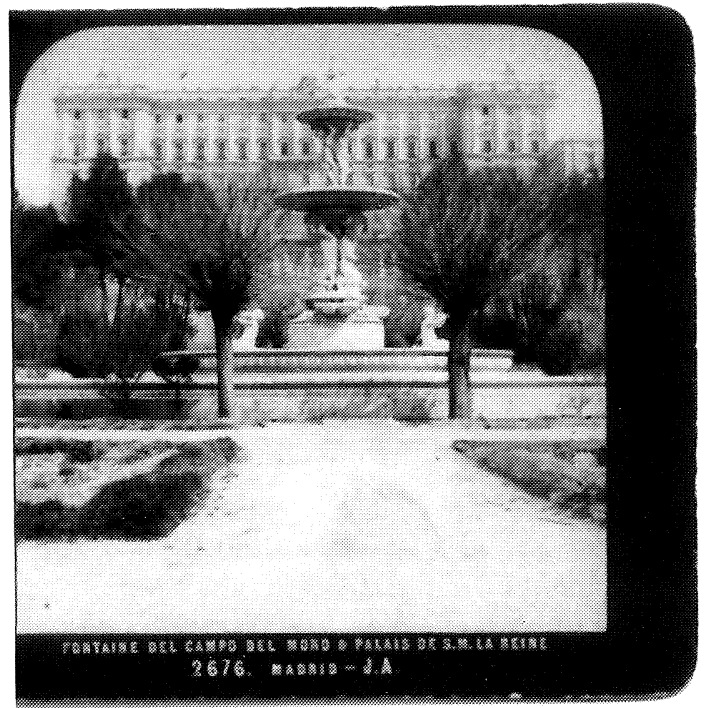

Fig. 15. 2674, Madrid, vue prise du palais du duc d'Osune. (Edición B.K. en tissue), Colección madridantiguo. Fig. 16. 2694, Palais de S.M. la reine a Madrid. (J.A., $2^{\mathrm{a}}$ Edición), Colección madridantiguo.

Fig. 17. 2684, Salle de musique au palais royal de Madrid. (J.A., $2^{\mathrm{a}}$ Edición), Colección madridantiguo.

Fig. 18. 2676, Fontaine del Campo del Moro au palais de S.M. la reine Madrid. (J.A., $1^{\mathrm{a}}$ Edición), Col. madridantiguo.

Igualmente cabe destacar la ausencia de interés por los temas taurinos, que por contra sí habían comenzado a interesar a algunos fotógrafos de la época e incluso anteriores. Tal vez, en parte, relacionada con las dificultades de retratar personas -aumentadas en el caso de la acción de una corrida-, pero, más probablemente, por no interesarle el tema a él o a sus clientes, ya que podría haber incluido escenas fijas o vistas de alguna plaza, pero éstas tan sólo aparecen fotografiadas y citadas en algún caso aislado, como parte de una vista aérea general de una ciudad. 


\section{Comentarios a las vistas reproducidas}

Cádiz. Fig. 1. Vista general tomada desde una de las torres de la catedral nueva. Se aprecia la otra torre y parte de la fachada neoclásica en primer plano y al fondo la ciudad vieja, con el castillo de Santa Catalina en la punta extrema de la península y el Campo del Sur a la izquierda bañado por el Atlántico. La vista tiene un logrado efecto estereoscópico por la inclusión de la torre en primer plano que nos sirve para poner de relieve la distancia respecto del resto de los edificios.

Córdoba. Fig. 2. Otra vista tomada desde una torre, en éste caso la del Alminar de la mezquita-catedral, que se construyó sobre el antiguo minarete. Vista sobre el patio de los naranjos (antiguo patio de abluciones) y sobre el barrio de plateros, con el Guadalquivir al fondo. Las representaciones de Córdoba son escasas, especialmente las de la mezquita-catedral (tan sólo ésta y dos interiores), sobre todo comparándolas con las numerosas de Granada, posiblemente debido a las dificultades creadas por el párroco, señaladas en el catálogo, que pretendía mandar en la catedral más que el propio Papa.

Sevilla. Fig. 3. En formato de «tarjeta de visita» o $C d V$. Una de las 11 vistas dedicadas a este patio mudéjar, dentro del palacio renacentista. Se puede ver una estatua de Atenea al fondo. Nos vuelve a indicar el interés por todo lo árabe -aunque fuese de época posterior-, que en Sevilla se complementa con otra considerable serie de patios y salas de los reales alcázares. También tiene una importante representación, con 13 vistas el palacio de San Telmo, residencia de los duques de Montpensier. El duque era un gran aficionado a la fotografía y, por otra parte, su nacionalidad francesa explica el interés que levantaba en el país vecino (como los personajes de la prensa del corazón actual) y la amplitud de la serie sevillana, frente a la granadina, ciudad preferida por los fotógrafos anglosajones.

Granada. Fig. 4. Se ve claramente que no se trata de una edición original de Andrieu, sino de una copia «pirateada» por un editor poco escrupuloso, lo cual era bastante habitual. Lo interesante del caso es que no se ha limitado a reproducir la fotografía, sino que ha incluido parte del titulo «Vue générale de la cour des lions» en las letras características de Andrieu e incluso se ven las esquinas redondeadas en la parte superior dentro de la nueva fotografía, ya que ha utilizado un único papel fotográfico para las dos imágenes. Las distintas salas de la Alhambra y algunas vistas generales prácticamente monopolizan la larga serie de la ciudad.

Alicante. Fig. 5. Vista del castillo de Santa Bárbara tomada desde el puerto, viéndose al pie del monte Benacantil la ciudad antigua, la playa del Postiguet y las casas de baños que se usaban en la época. Varias vistas generales más de la ciudad, algunas de ellas tomadas a la inversa, desde el castillo, completan la serie.

Valencia. Fig. 6. Otra vista desde la torre de una catedral, en este caso del Miguelete, mirando a la iglesia de San Nicolás. En este caso no hay ningún detalle de primer plano que nos sirva de referencia.

El Escorial. Fig. 7. Una de la vistas, desde distintas perspectivas, del edificio mandado levantar por Felipe II en 1563. En éste caso tomada desde su parte posterior, desde lo que parece un solar. No parece que los interiores le interesaran, o no pudo fotografiarlos. En el catálogo esta vista se señala erróneamente como tomada desde la montaña, lo que además no coincide con el título escrito en la vista. Los errores en las inscripciones en vistas estereoscópicas son frecuentes, sobretodo cuando se escribían a mano, equivocándose, a veces, incluso en la ciudad a la que corresponden.

Toledo. Fig. 8. Una de las múltiples vistas editadas sobre el Tajo con motivo de fotografiar los distintos puentes y vistas generales de la ciudad. Se puede deducir que este tipo de vista fue de especial agrado para Andrieu, el cual, como hemos dicho, llegó a incluir una persona

$A E A$, LXXVIII, 2005, 312, pp. 381 a 396 
posando en una de ellas. Desde un punto de vista estético y estereoscópico están todas muy logradas y de alguna manera evocan las vistas en pintura de El Greco.

\section{Recorrido por el Madrid de 1867}

Fig. 9. Palacio neoárabe levantado en 1865 frente al Museo del Prado - $\mathrm{P}^{\circ}$ del Prado esquina a Lope de Vega-, por el capitalista Xifret y que lamentablemente será derribado en los años 50 para construir el actual Ministerio de Sanidad. Muestra una vez más el interés por lo árabe, aunque en este caso sea totalmente recreado. Vista general del edificio, pero un tanto aislada del entorno.

Fig. 10. Fachada al Paseo del Prado del actualmente denominado Museo del Prado, entonces Real Museo de Pinturas y Esculturas de S.M. Destacan los jardines, plantados ca. 1860 y contrastan con el desértico aspecto anterior que se ve en la imagen de Clifford de 1853 publicada por mí en el Boletín del Museo del Prado (Hervás León, Miguel «Una nueva fotografía del Museo del Prado en 1853», Boletín del Museo del Prado, Tomo XXI, n. ${ }^{\circ} 39,2003$, pág. 57).

Fig. 11. Una de las tres vistas que realizó de las galerías de escultura ${ }^{16}$ de la planta baja del Museo del Prado. La 2665 y la 2667 corresponden a la Sala Norte o de la «izquierda» y la 2666 a la Sala Sur o de la «derecha», no existiendo la vista complementaria de esta (afortunadamente Laurent sí produjo este cuarto ángulo). No realizó vistas de las salas de cuadros ${ }^{17}$. A lo largo del siglo xx estas galerías serán ocupadas por cuadros.

Fig. 12. Vista frontal y general de la fachada de la Basílica de N. ${ }^{a}$ S. ${ }^{a}$ de Atocha, con su patio o atrio delantero, cerrado por una arcada. Iglesia de remoto origen, vinculada a la corona y que lamentablemente será derribada por amenazar ruina en 1887 para levantar una nueva con proyecto neobizantino de Fernández Arbós, que tan sólo se llevó a cabo parcialmente (El claustro -que aloja el panteón de hombres ilustres- y el gracioso campanile). La basílica como tal no se realizó sino con otro proyecto mucho más sencillo y tardío, que ardió en Julio de 1936 y posteriormente sustituida, a su vez, por la actual. Otra de las vistas generales de un edificio, pero una vez más, un tanto aislada.

Fig. 13. Fuente de la Fama en la Plaza de Antón Martín, de estilo churrigueresco, diseñada por Pedro de Ribera, instalada allí en 1766. Uno de tantos monumentos «viajeros» de Madrid. Será trasladada a principios del siglo xx al Parque del Oeste y más adelante a los jardines que llevan el nombre del arquitecto detrás del Museo Municipal. Al fondo se ve el popular Café de Zaragoza.

Fig. 14. Primer plano de la estatua creada en Florencia por Juan de Bolonia y Pietro Tacca. Trasladada a la Plaza Mayor en 1848 desde la Casa de Campo. Estatua de gran mérito pero de poca fortuna, ya que, pocos años después, en 1873, será desmontada y troceada por la primera república y nuevamente derribada y rota en 1931 cuando se proclame la segunda. De

\footnotetext{
${ }^{16}$ Un interesante y detallado estudio del contenido de estas vistas ha sido realizado por el conservador de escultura del Museo del Prado D. Stephan F. Schröder. La Galería de Escultura del Museo del Prado a mediados del s. XIX - Una reconstrucción. En prensa, para su publicación por la Universidad de Sevilla, (Congreso Internacional: Arqueología, coleccionismo y antigüedad. España e Italia en el siglo xIX, 2005).

${ }^{17}$ Pérez Gallardo, Helena, La democracia del arte: El Museo del Prado, objetivo de la fotografía en op.cit. El Grafoscopio, pp. 262 y ss., señala las dificultades que existían para realizar fotografías de las obras del Real Museo en los primeros años. Así, salvo algunas imágenes puntuales no documentadas, las primeras referencias a permisos excepcionales que se conservan son de 1858 para cuadros y de 1862 para esculturas. El hecho de que Andrieu no fotografiase las salas de pinturas pudo deberse a que una imagen con esculturas normalmente produciría una imagen estereoscópica de mejor relieve que una sala de cuadros o, más probablemente, a que fuese más fácil lograr un permiso para fotografiar aquellas salas, ya que Laurent estaba fotografiando los cuadros casi en «exclusiva», como explica ésta autora. En cualquier caso, no se refleja en el artículo ninguna referencia a Andrieu o a la solicitud del permiso para tomar estas vistas, por lo que sería interesante investigar si éste se conserva.
} 
fondo se aprecia parte de la fachada de la Casa de la Panadería, pero difícilmente ésta imagen tan encajonada nos puede dar una idea del aspecto de la Plaza Mayor.

Fig. 15. Una de las dos vistas generales de Madrid -con otra desde el observatorio-, en este caso desde el palacio del Duque de Osuna, que será derribado para la construcción del seminario Conciliar en las Vistillas. Al fondo se ve el Palacio Real y más allá el Cuartel de la Montaña, terminado en 1865. En primer plano se ven las casas que se levantaban a ambos lados de la calle de Segovia y que en su mayor parte desaparecerán, dejando paso a jardines, a lo largo del siglo xx.

Fig. 16. Patio de la Armería del Palacio Real, con la fachada sur de éste. Imagen tomada ante o bajo el Arco de la Armería antigua, edificio exento levantado por Felipe II en estilo flamenco, único superviviente del incendio del antiguo Alcázar en 1734 y que perecerá a su vez en otro en 1884, siendo derribado y sustituido por una verja que cierra la plaza en 1893. Sus cimientos han salido a la luz recientemente en las excavaciones previas a la construcción del Museo de Colecciones Reales.

Fig. 17. Típico salón del Palacio Real, de uso privado de la reina, con decoración palaciega al gusto de la época. Téngase en cuenta el uso de la denominación del «Palacio de S. M. la Reina» en el título, ya que tan sólo faltaban unos meses para la Revolución de 1868 que llevó a Isabel II al destierro en el mes de Septiembre. El uso de termino S.M. le Roi en otras imágenes similares de la serie se entiende referido a salones para uso de su marido $-\mathrm{o}$ sino sería un error, ya que faltan aún muchos años para que su hijo Alfonso XII sea proclamado rey-.

Fig. 18. Fuente de las Conchas de Ventura Rodríguez en el Campo del Moro, diseñada originalmente para el palacio de Boadilla del Monte y trasladada a y desde la posesión de Vista Alegre (Vallecas) a los jardines del palacio real, que en esos momentos se estaban replantando tras siglos de abandono, convertidos en un vertedero. Bonita composición con la fachada Oeste, menos encajonada de la habitual.

Analizando la serie en su conjunto y a modo de conclusión, podemos decir que, -según hemos ido apuntando-, si bien la mayoría de las imágenes no poseen ni la brillantez y calidad que se llegó a alcanzar con el tiempo en otras series estereoscópicas, ni la inspiración creativa y estética que logran contemporáneos suyos ${ }^{18}$ y que incluso él mismo nos muestra en muchas imágenes de otras de sus series ${ }^{19}$, no por ello la serie deja de ser una de las principales series que se produjeron sobre España, interesantísima como fuente de informaciones y con muchas imágenes de gran originalidad y belleza. Por ello pensamos que sería de gran interés un estudio en profundidad que continué la labor del trabajo aquí esbozado.

\footnotetext{
${ }^{18}$ Por ej., Laurent en esas mimas fechas también tomaba estereoscopias y una comparación de las imágenes tomadas por ambos fotógrafos de un mismo sitio suele favorecer casi siempre a éste último, al menos atendiendo a criterios estéticos actuales.

${ }^{19}$ Tal vez la explicación para esta aparente diferencia estilística entre muchas de sus fotos de otras series y las de España, sea una cuestión de concepto y de libertad creativa. Cuando Andrieu toma una vista en España, su objetivo principal es enseñar la ciudad a personas para quienes es totalmente desconocida; se trata simplemente de enseñar una buena imagen, no necesariamente creativa, al modo en que lo harán posteriormente las postales. Por el contrario, cuando Andrieu fotografía una escena en Francia, de alguna manera, aunque sea a nivel subconsciente, es posible que no tenga la misma idea o propósito en la cabeza; Si bien es posible que muchos espectadores tampoco conozcan la ciudad, otros seguramente sí por lo que serán más exigentes- $\mathrm{y}$, en cualquier caso, su imagen habrá de competir con las vistas del mismo sitio de otros fotógrafos, por lo que posiblemente la disposición creativa sea diferente. Ya no se trata de realizar una tarjeta postal, sino de tomar una imagen interesante. Veámoslo con un ejemplo: Cuando fotografía un puente en España, el objetivo es mostrar el puente, por lo que una simple vista más o menos lateral valdrá perfectamente, mientras que cuando la hace con esa otra idea, se puede dejar llevar por una imagen más creativa y así lograr, probablemente un resultado más artístico: como por $\mathrm{Ej}$. un puente visto desde debajo, que supone una vista ciertamente vanguardista.
}

AEA, LXXVIII, 2005, 312, pp. 381 a 396 


\section{Listado de la serie}

\begin{tabular}{|c|c|c|c|}
\hline \multirow{3}{*}{2422} & Cadix (Cádiz) & & Malaga (Málaga) \\
\hline & Vue générale de Cadix prise du fort de San & 2517 & Le port, vue prise du phare \\
\hline & Sebastien & 2518 & Le chateau pris des ruines mauresques \\
\hline 2423 у 24 & Vue g. de Cadix prise de Torre-de Vigia & 2519 & Porte d'entrée a la cathédrale \\
\hline 2425 y 26 & Vue g. de Cadix prise de la cathédrale & 2520 & Vue générale de Malaga prise de la forteresse \\
\hline 2428 & Observatoire astronomique & 2521 & Porte d'entrée a la cathédrale \\
\hline & Cordoue (Córdoba) & 2522 & Vue générale de Malagá \\
\hline 2429 у 30 & Moulins mauresque sur le Guadalquivir & 2523 & Porte d'éntrée a l'Archevêché \\
\hline 2431 & Tour de la mosquée & 2524 & Le port de Malaga \\
\hline 2432 & Le triomphe á Cordoue & 2525 y 26 & Vue de Malaga \& de la cathédrale \\
\hline 2433 & Porte déntrée á l’Archevêché & 2527 & Côte de la Calette \\
\hline 2434 y bis & Interieur de la mosquée & & Gibraltar \\
\hline 2435 & Vue g.de C. prise de la Tour de la mosquée & 2528 & Gibraltar pris des ruines de Sant-Phillipe \\
\hline 2436 у 37 & Tour et pont mauresques & 2529 & Gibraltar pris de la baterie de mer \\
\hline 2438 & Porte du pont de Cordoue & 2530 & Le Môle neuf pris de Bellevue \\
\hline 2439 & Porte mauresque (maison Trevilla) & 2531 & Vue prise de la baterie du Sud \\
\hline 2440 & Tour mauresque de la Malmuerta & 2532 & Casernes d'infanterie prises de la baterie super.ieure \\
\hline 2440 bis & Chapelle mauresque dans l'int. de la mosquée & 2533 & La tour du chateau \\
\hline & Séville (Sevilla) & 2534 & La tour mauresque \\
\hline 2441 a 45 & Patio de la Casa de Pilatos & 2535 & Vue g. de Gibraltar prise du chemin de Magnetto \\
\hline 2446 & Partie superieure du patio de la Casa de Pilatos & 2536 & Vue générale de la porte de mer \\
\hline 2447 y 48 & Patio de la Casa de Pilatos & 2537 & Phare de la pointe d'Europe \\
\hline 2449 a 51 & Fontaine \& patio de la Casa de Pilatos & 2539 & Télégraphe marin pris du chemin du pasteur \\
\hline 2452 a 56 & Patio du palais de l'Alcazar & 2540 & La tour de $\mathrm{O}^{\prime} \mathrm{Hara}$ \\
\hline 2457 y 58 & Partie superieure du patio de las Muñecas & & Grenade (Granada) \\
\hline 2459 & Porte d'entrée au salon des ambassadeurs & 2542 y 43 & Vue générale prise de la Silla del Moro \\
\hline 2460 & Porte de Triana a Séville & 2544 y 46 & Cour des Lions (Ouest) palais de l'Alhambre \\
\hline 2461 & Porte d'entrée a l'Archeveché & 2545 y 47 & Cour des Lions (Est) \\
\hline 2462 & Palais de I'Ayuntamiento & 2548 & C. des L. et porte d'entrée a la S.des dos hermanas \\
\hline 2463 & Porte mauresque de l'église Saint-Paul & 2549 & Fontaine de Charles V \\
\hline 2464 & Cirque de Toros \& le Guadalquivir & 2550 & Vue générale prise de la tour de la Vela \\
\hline 2465 & Jardins du palais de l'Alcazar & 2551 & Pavillon Est dans la Cour des Lions \\
\hline 2466 & Vue générale de Séville & 2552 & Cour du palais de Charles V au p.de l'Alhambre \\
\hline 2467 a 71 & Porte d'entrée a la Cathédrale & 2553 & Interieur de la mesquitta \\
\hline 2472 & Porte du Pardon & 2554 & Cour de la chapelle au palais de l'Alhambre \\
\hline 2473 & Torre del Oro a Séville & 2555 & C. des Lions et entrée aux salles de la Justice. \\
\hline 2474 & Patio de las Muñecas et perspective du salon des & 2556 & Façade du pavillon Est (Cour des Lions) \\
\hline & ambassadeurs au palais de l'Alcazar & 2557 & Vue g. prise de la tour de la Infanta a l'Alhambre \\
\hline 2475 y 76 & Façade et porte d'entrée au palais de l'Alcazar & 2558 & Entrée de la Cour des Lions \\
\hline 2477 & Eglise et porte mauresque de Saint-Marc & 2559 & Cour des Lions au palais de l'Alhambre \\
\hline 2478 y 79 & La Giralda a Séville & 2560 & Vue générale de l'Alhambre \\
\hline 2481 & Pont de fer et le Guadalquivir & 2561 & Agimez de la Salle des Ambassadeurs a l'A.lhambre \\
\hline 2482 & Vue générale de la Cathédrale & 2562 & Cour de la Justice a l'Alhambre \\
\hline 2483 & Le Guadalquivir et le port de Séville & 2563 & Galerie Ouest de la Cour des Lions \\
\hline 2484 & Panorama de Séville pris du haut de la Giralda & 2564 & Pavillon Ouest de la Cour des Lions \\
\hline 2485 & Patio de las Doncellas au palais de l'Alcazar & 2565 & Couvent du Sacramento \\
\hline 2486 & Patio de las Doncellas et porte d'entrée a la salle des & 2566 y 67 & Cour des Myrtes au palais de l'Alhambre \\
\hline & ambassadeurs au palais de l'Alcazar & 2568 & Palais de Justice \\
\hline 2487 & Emplacement ou etait le trone des rois maures & 2569 & Vue générale de la Cour des Lions \\
\hline 2488 & Patio de las Muñecas au palais de l'Alcazar & 2570 & Tour de los Picas \\
\hline 2489 y 90 & Salon des Ambassadeurs au palais de l'Alcazar & 2571 & Interieur de la coupole de la Salle des Abencérages \\
\hline 2491 & Oratoire particulier d'Isabelle Catholique a l'A.lcazar & 2572 & Int. de la coupole de la Salle des dos hermanas \\
\hline 2492 & Porte d'entrée a la chambre a coucher des rois & 2573 & Pavillon Ouest de la Cour des Lions \\
\hline & maures au palais de l'Alcazar & 2574 & Pavillon dans la Cour des Lions \\
\hline 2493 a 96 & Patio de las Doncellas au palais de l'Alcazar. & 2575 & Vue générale de la Cour des Lions \\
\hline 2497 & Le Guadalquivir et la Tour del Oro & 2576 & Entrée du salon du Generalife \\
\hline 2498 & Porte d'entrée au palais de l'Alcazar & 2577 & Cour de la chapelle et fenêtre de Boabdil \\
\hline 2499 a 01 & San-Telmo, palais de S.A.R. le duc de Montpensier & 2578 & Entrée de la Cour des Lions \\
\hline 2502 a 04 & Patio du palais de S.A.R. le duc de Montpensier & 2579 & Salle de l'Indaraja au palais de l'Alhambre \\
\hline 2505 y 06 & Galerie (Interieur du p.de S.A.R. le d.de M.) & 2580 & Palais de Charles V a l'Alhambre \\
\hline 2507 & Salon de la Vierge du p.de S.A.R. le d.de M. & 2581 & Cour des Lions coté Ouest \\
\hline 2508 & Salle d'attente (Int.du p.de S.A.R. le d.de M.) & 2582 & Salle de la Justice a l'Alhambre \\
\hline 2509 y 10 & Salon de Reception (Int.du p.de S.A.R. le d.de M.) & 2583 & Torre de Agua au palais de l'Alhambre \\
\hline 2511 & Cathédrale de Séville prise du palais & 2584 & Pavillon Est de la Cour des Lions \\
\hline 2512 & Le Guadalquivir pris du palais San Telmo & 2585 & Cour des Lions \\
\hline 2513 & Entrée principale au p.de S.A.R. le duc de Montp. & 2586 & L'Alhambre, Vue prise de la tour de la Vela \\
\hline 2514 & Cathédrale de Seville & 2587 & Gallerie de la salle des Abencérages a l'Alhambre \\
\hline 2515 & Cathédrale de Séville et place du Triumphe & 2588 & Tour de Candil et de los Picos au p.de l'Alhambra \\
\hline 2516 & Le Guadalquivir et le palais San Telmo & 2589 & Vue générale de l'Alhambre \& du Generalife \\
\hline
\end{tabular}

$A E A$, LXXVIII, 2005, 312, pp. 381 a 396 


\begin{tabular}{|c|c|}
\hline 2590 a 93 & $\begin{array}{l}\text { Porte de la salle des Dos Hermanas a l'Alhambra } \\
\text { Cartagéne (Cartagena) }\end{array}$ \\
\hline 2594 & Vue g. de Cartag. prise de la forteresse Talaya \\
\hline 2595 & Place \& cirque des taureaux \\
\hline 2596 & Quartier Sta. Lucie \\
\hline 2597 & Entrée du port \\
\hline 2598 & Consulat de France \& Port \\
\hline 2599 & Cartagéne et le castillo Talaya \\
\hline 2600 & Vue génértale de l'Arsenal \\
\hline 2601 & Entrée du port \\
\hline 2602 у 04 & Vue générale \\
\hline \multirow[t]{2}{*}{2603} & Vue générale de l'Arsenal \\
\hline & Alicante \\
\hline 2605 & Vue générale \\
\hline 2606 & Alicante \& le port \\
\hline 2607 & Vue prise du castillo \\
\hline 2608 & Forteresse d'Alicante prise du port \\
\hline \multirow[t]{2}{*}{ 2608bis } & Alicante \& le port \\
\hline & Valence (Valencia) \\
\hline 2609 & Lonja de la seda \\
\hline 2610 & Vierge de los desamparados \\
\hline 2611 & Tour de Miguelete et dôme de la Cathédrale \\
\hline 2612 & Porte d'entrée a la Cathédrale \\
\hline 2613 & Tour de Miguelete et porte d'entrée a la Cathédrale \\
\hline 2614 y 15 & Vue générale prise de la tour de la Cathédrale \\
\hline 2616 & Fontaine de la Alameda \\
\hline \multirow[t]{2}{*}{ 2616bis } & Porte de Serrano \\
\hline & Barcelone (Barcelona) \\
\hline 2617 & Vue prise du Fort Monjuich \\
\hline 2618 & Port des Pecheurs \& Fort Manjuich \\
\hline 2619 & Barcelone. Vue prise de Vista-Allegre \\
\hline 2620 & Place Royale et entrée du Port \\
\hline 2620 bis & Fontaine de la place royale \\
\hline 2621 a 23 & Vue générale \\
\hline 2624 a 26 & Vue de Barcelone prise du Fort Monjuich \\
\hline 2627 & Le Port pris de la tour du Capitaine \\
\hline 2628 y bis & Le Port \\
\hline 2629 & La Rambla \\
\hline 2630 & Tour du Capitaine \& le Fort Monjuich \\
\hline \multirow[t]{2}{*}{ 2630bis } & Interieur de l'Arsenal \\
\hline & Aranjuez \\
\hline \multicolumn{2}{|c|}{ 2631a 32bis Palais Royal } \\
\hline 2633 & Cabinet de travail de S.M. la reine au P.Royal \\
\hline 2634 y bis & Salle de chine ou chambre de porcelaine au P.Royal \\
\hline 2635 & Salle de toilette de S.M. la reine au P.Royal \\
\hline 2636 & Salon des Ambassadeurs au P.Royal \\
\hline \multirow[t]{2}{*}{$2636 \mathrm{bis}$} & Palais de S.M. la reine Maria Cristina \\
\hline & L'Escurial (El Escorial) \\
\hline 2637 & Palais Royal de l'Escurial pris des Jardins \\
\hline 2638 & Palais Royal pris de la montagne \\
\hline \multirow[t]{2}{*}{2639 a 42} & Palais Royal \\
\hline & Toléde (Toledo) \\
\hline 2643 & Pont St Martin \\
\hline 2644 & Porte de Cambrone \\
\hline 2645 y 46 & Toléde. Vue prise du sepulcre du roi maure \\
\hline 2647 & Le Tage pris du sepulcre du roi maure \\
\hline 2648 y 49 & Porte du Soleil \\
\hline 2650 & Porte de St Martin pris de la promenade \\
\hline 2651 y 52 & Le Tage et le Pont de l'Alcantara \\
\hline 2653 & Eglise de St Juan de los Reyes \\
\hline 2654 & Façade \& porte d'entrée de la Cathedrale \\
\hline 2655 & Porte d'entrée au college militaire \\
\hline 2656 & L' Alcazar pris du ravin \\
\hline 2656 bis & L'Alcazar \\
\hline
\end{tabular}

\begin{tabular}{|c|c|}
\hline 2657 & Le Tage \& le barrio Santa Lucia \\
\hline 2658 & Porte Visagra \\
\hline 2659 & Ruines du château de San Servando \\
\hline 2660 & Le Tage \& les moulins mauresques \\
\hline 2661 & Le Tage \& les moulins de la Vieja \\
\hline 2662 & Cloitre de San Juan de los Reyes \\
\hline 2663 & Pont de l' Alcantara \\
\hline 2664 & $\begin{array}{l}\text { Le Tage \& le pont St. Martin } \\
\text { Madrid }\end{array}$ \\
\hline 2665 a 67 & Int. de la galerie de sculpture au musée de Madrid \\
\hline 2668 & Façade principale du théâtre royal \\
\hline 2669 у 70 & Palais de S.M. la Reine \\
\hline 2671 & Fontaine de Neptune au Prado \\
\hline 2672 & Porte d'Alcala \\
\hline 2673 & Vue du P.de S.M. la Reine pris del Campo del Moro \\
\hline 2674 & Madrid. Vue prise du P. de M. le duc d'Osune \\
\hline 2675 & Statue de Philippe IV place d'Orient \\
\hline 2676 & Fontaine del Campo del Moro au P.de S.M. la Reine \\
\hline 2677 & Fontaine de la place Antonio Martin \\
\hline 2678 y bis & Fontaine de Cybele au Prado \\
\hline 2679 & Salon du Trône au palais \\
\hline 2680 & Trône de S.M. le Roi au palais \\
\hline 2681 & Salon \& oratoire particulier de S.M. la Reine \\
\hline 2682 & Salon du trône de S.M. la Reine \\
\hline 2683 y bis & Salon de receptions de S.M. le Roi au palais \\
\hline 2684 & Salle de musique au palais \\
\hline 2685 & Cabinet particulier de S.M.le Roi au palais \\
\hline 2686 & Place mayor \& statue de Philipe III \\
\hline 2687 & Place Isabelle II \\
\hline 2688 & Fontaine de la Alcachofa \\
\hline 2689 & Chambre des deputés \\
\hline 2690 & Façade principale de l'église d'Atocha \\
\hline 2691 & Porte de Toledo \\
\hline 2692 & Eglise de las Salesas Reales \\
\hline 2693 & Porte de Saint-Vinçent \\
\hline 2694 & Palais de S.M. la Reine \\
\hline 2695 y 96 & Pont de Tolede \\
\hline 2697 & Vue de Madrid prise de l'observatoire \\
\hline 2698 & Pont de Ségovie \\
\hline 2699 & Palais de S.M. la Reine \\
\hline 2700 & Palais arabe de Chifret \\
\hline 2701 & Façade principale du musée royal \\
\hline 2702 & Observatoire astronomique \\
\hline \multirow[t]{2}{*}{$2703 \mathrm{y}$ bis } & Fontaine D'Apollon au Prado \\
\hline & Burgos \\
\hline 2704 & Cathédrale de Burgos \\
\hline 2705 у 06 & Façade principale de la Cathédrale \\
\hline 2707 & Arco de Sta. Maria \\
\hline 2708 & Porte d'entrée a la cartuja de Miraflores \\
\hline \multirow[t]{2}{*}{2709} & Porte d'entrée a la Cathédrale \\
\hline & Guipúzcoa \\
\hline 2710 & Pont international a Hendaye \\
\hline 2711 & Passage la tour St Pierre \\
\hline 2712 & Vue générale du Passage et entrée du port \\
\hline 2713 & Habitations de pêcheurs et Tour St-Pierre Passage \\
\hline 2714 & Baterie de la reine et île $\mathrm{S}$. Claire a $\mathrm{S}$. Sebastien \\
\hline 2715 & Vue générale de S. Sebastien prise de la forteresse \\
\hline 2716 & Pont de S. Sebastien \\
\hline 2717 & Île Sainte-Claire a S. Sebastien \\
\hline 2718 & Forteresse de S. Sebastien \\
\hline 2719 & Porte d' entrée a l' église de St Marc a S. Sebastien \\
\hline 2720 & Vue générale de Fontarabie \\
\hline 2721 y 22 & Rue Royale et église de St Marco a Fontarabie \\
\hline 2723 & Quartier des marins a Fontarabie \\
\hline
\end{tabular}

